\title{
Assessing the Impact of Training on Knowledge Level of Dairy Farmers of Punjab during Transitional Period
}

\author{
Niharika Thakur, Parminder Singh", Rajesh Kasrija and S. K. Kansal
}

Dept. of Veterinary and Animal Husbandry Extension Education, Guru Angad Dev Veterinary and Animal Sciences University (GADVASU), Ludhiana, Punjab (141 004), India

\section{Corresponding Author}

Parminder Singh

e-mail: pmschawla@gmail.com

\author{
Article History \\ Article ID: AR1934 \\ Received in 05 ${ }^{\text {th }}$ December, 2018 \\ Received in revised form $13^{\text {th }}$ January, 2019 \\ Accepted in final form $14^{\text {th }}$ January, 2019
}

\begin{abstract}
The study was undertaken to assess the impact of training on knowledge level of dairy farmers of Punjab regarding incidence of various transitional diseases and on management, breeding and feeding practices during transitional period. A structured interview schedule was made for interviewing 250 dairy farmers of Punjab, India. Among the transitional diseases incidence of anoestrous, mastitis, retained placenta, repeat breeding, metritis, milk fever, dystokia and ketosis were $59.6 \%, 52 \%, 38 \%, 30 \%, 22.4 \%, 18 \%, 14.8 \%$ and $10.4 \%$ respectively. Special dry feed feeding, special mineral mixture feeding and conception rate at dairy farm was found to be significantly associated $(p<0.01)$ with training. Particular diseases like metritis and repeat breeding were significantly associated $(p<0.05)$ with training. However, parameters like dry period, normal calving, heats missed after calving were found to be non-significantly different between farmers who has taken training and not. But, the awareness perceived by the farmers after training in relation to feeding, breeding, management and health status was significantly higher during transitional period as compared to the farmers who did not undertake any training. So, proper coverage of topic on management of dairy animals during transitional period is must for making a training programme effective. Also, still more awareness and extension activities on transitional period management are the need of hour. The extension machinery should be constructed in such a way that it provides a bridge between scientists/researchers and dairy farmers for successful implementing the training programme for transitional period.
\end{abstract}

Keywords: Dairy, farmer, knowledge, Punjab, training, transitional period

\section{Introduction}

Punjab is one of the leading states in dairying and milk production, producing $11.28 \mathrm{mt}$ of milk, of the total milk production of country which is $165.4 \mathrm{mt}$ (National Dairy Development report, 2016-17). Despite rapid advances in the animal husbandry technologies and their role in improving livestock sector, productivity of this sector is still very low (Chander et al., 2010). The success of dairy farming lies in ensuring proper and optimal reproductive rhythm of an individual animal in the herd (Agarwal et al., 2005). The reproductive potential of an animal is affected by breeding practices, feeding, management and health care undertaken by a dairy farmer especially during transitional period (Thakur, 2018). The transitional period in dairy animals is defined as the last three weeks before parturition to three weeks after parturition (Grummer, 1995). The importance of transition period is that various management and nutritional interventions during this sensitive period can prevent animal from undergoing stress and becoming immunosuppressant. But, there is poor diffusion and adoption of livestock technologies at field level (Melesse et al., 2013). The Knowledge level of dairy farmers about various recommended practices is medium to low (Aulakh et al., 2011; Kasrija, 2016). Also, there is urgent need for spreading awareness by extension specialists and formulating suitable strategy for enhancing adoption level for curtailing reproductive disorders (Kasrija et al., 2016b). For this training and education can play an important role in enhancing awareness level of dairy farmers about control of various transitional diseases (Thakur et al., 2018). Also, the training can plays an instrumental role in directing farmers towards various management, breeding and feeding practices, thereby preventing them to suffer from economic losses that they may occur due to their negligence or their unawareness. The present study was planned to assess the impact of training on occurrence of disorder related with transitional period and knowledge level of farmers about practices followed at dairy farm during transitional period.

\section{Materials and Methods}

An appropriate research instrument i.e. a structured 
interview schedule was prepared to collect data from the dairy farmer's during transitional period. While preparing this structured interview schedule, an effort was made to make it self-explanatory by keeping in view the knowledge level of the dairy farmers in context to transitional period. An all-out attempt was made to incorporate the number of items (questions) relating to transitional period in the interview schedule by scrutinising latest literature, research journals and after discussing with subject matter experts. This interview schedule was first pretested on 40 separate respondents, which were not the part of the study. Very easy, very difficult and confusing items were eliminated from final interview schedule. This pretested final structured interview schedule was used as a tool for gathering information from 250 randomly chosen dairy farmers from various locale of Punjab during year 2017-2018. The farmers were interviewed personally to avoid influence of other farmers. The incidence of various diseases occurring during transitional period (such as Dystokia, Retention of Placenta (ROP), Mastitis, Anoestrus, Milk fever, Ketosis, Metritis and Repeat breeding) at the farm were noted. The impact of training on incidence level of transitional diseases and knowledge level of farmers about practices (management, breeding and feeding) followed at dairy farm during transitional period was assessed. The data was tabulated and put to suitable statistical analysis with the help of SAS 9.3 system Carry N C, USA.

\section{Results and Discussion}

Table 1 illustrated that out of 250 farmers, 59.6\%, 52\%, 38\%, $30 \%$ and $14.8 \%$ dairy farmers had incidence of anoestrous, mastitis, retention of placenta, repeat breeding and dystokia

\begin{tabular}{lccc}
\hline \multicolumn{3}{l}{ Table 1: Frequency of incidence of transitional diseases } \\
\hline Parameter & Category & Frequency $(\mathrm{n}=250)$ & Percentage \\
\hline Dystokia & Yes & 37 & 14.80 \\
& No & 213 & 85.20 \\
ROP & Yes & 95 & 38.00 \\
Mastitis & No & 155 & 62.00 \\
& Yes & 130 & 52.00 \\
Anoestrous & No & 120 & 48.00 \\
& Yes & 149 & 59.60 \\
Milk Fever & Yes & 101 & 40.40 \\
& No & 45 & 18.00 \\
Ketosis & Yes & 205 & 82.00 \\
& No & 26 & 10.40 \\
Metritis & Yes & 224 & 89.60 \\
Repeat & No & 56 & 22.40 \\
breeding & Yes & 194 & 77.60 \\
\hline
\end{tabular}

respectively at their dairy farm. However, milk fever, ketosis and metritis were found to be $18 \%, 10.4 \%, 22.4 \%$ respectively. Dua (2003) scrutinised the comparative disease susceptibility of cattle and buffalo in Punjab by examining 802 female cattle and 2316 buffaloes over a 6 year period and reported the incidence of various transitional diseases such as anoestrus (43.0\% and $55.5 \%)$, repeat breeding (35.3\% and $12.8 \%$ ), retained placenta (6.4\% and $4.7 \%)$, dystokia (3.5\% and $8.3 \%$ ) and abortion (2.6\% and 3.1\%) respectively. Kasrija (2016) also reported almost similar incidence of anoestrous in dairy farms of sub mountain undulating region of Punjab. The farmers did not provide proper nutrition during the dry period and even duration of dry period was short in that region. This resulted in negative energy in animals and they failed to ovulate. Mir et al., 2015 reported that the incidence of mastitis was high due to lack of management practices viz. hygiene practices related to milking. So, in present study the importance of training is highlighted for control of anoestrus and mastitis.

Table 2 depicts that training was found to be significant associated $(p<0.05)$ for control of particular diseases like metritis and repeat breeding. Incidence of various diseases like metritis and repeat breeding were found to be less for farmers who undertook training i.e. $69.64 \%$ and $68 \%$ respectively. Other transitional diseases were found to be non significantly associated with training, but still the impact of training is that there was less incidence of these diseases at the farms where dairy farmer had taken training. Kasrija et al. (2016a) also reported the catalytic role of extension agencies for knowledge dissemination and high lightens separate strategies to be undertaken for improving the Reproduction Acquaintance level (RAL) of farmers running different dairy units for increasing profit. Aparna and Hundal (2016) demonstrated that awareness perceived by the farmers after training in terms of management, feeding and breeding were significantly higher which further helped in control of various incidence of diseases in the farms.

Table 3 depict that special dry feed and special mineral mixture feeding varied significantly $(p<0.01)$ with training. Parmar (2014) also reported that Knowledge level score of organized as well as unorganized farmers regarding their general management practices, breeding, feeding, health care practices and technical knowledge was negatively correlated to the incidence of reproductive disorders at their farms.

Also, the $57.83 \%$ farmers who undertook training were offering special dry feed to their animals. Conception rate was also found to be $\geq 80 \%$ for the farmers (52.33\%), which is significantly $(p<0.05)$ higher at those farm where dairy farmer has undergone a training. But one aspect of training that has to be improved was feeding of special mineral mixture, as $48.72 \%$ farmers were not feeding special mineral mixture. Tewari et al. (2010) also reported that the interaction between nutrition and reproduction needs particular attention to overcome nutrient imbalances. The nutritional deficiency caused infertility problems in crossbred cattle and the highest 


\begin{tabular}{|c|c|c|c|c|c|}
\hline Parameter & $\begin{array}{l}\text { Cat- } \\
\text { egory }\end{array}$ & Impact & $\begin{array}{c}\text { No } \\
\text { impact }\end{array}$ & $\begin{array}{l}\text { Overall } \\
(n=250)\end{array}$ & $\begin{array}{c}\chi^{2} \\
\text { value }\end{array}$ \\
\hline \multirow[t]{2}{*}{ Dystokia } & Yes & $\begin{array}{c}14 \\
(37.84)\end{array}$ & $\begin{array}{c}23 \\
(62.16)\end{array}$ & $\begin{array}{c}37 \\
(14.80)\end{array}$ & 0.30 \\
\hline & No & $\begin{array}{c}91 \\
(42.72)\end{array}$ & $\begin{array}{c}122 \\
(57.28)\end{array}$ & $\begin{array}{c}213 \\
(85.20)\end{array}$ & \\
\hline \multirow[t]{2}{*}{ ROP } & Yes & $\begin{array}{c}35 \\
(36.84)\end{array}$ & $\begin{array}{c}60 \\
(63.16)\end{array}$ & $\begin{array}{c}95 \\
(38.00)\end{array}$ & 1.67 \\
\hline & No & $\begin{array}{c}70 \\
(45.16)\end{array}$ & $\begin{array}{c}85 \\
(54.84)\end{array}$ & $\begin{array}{c}155 \\
(62.00)\end{array}$ & \\
\hline \multirow[t]{2}{*}{ Mastitis } & Yes & $\begin{array}{c}54 \\
(41.54)\end{array}$ & $\begin{array}{c}76 \\
(58.46)\end{array}$ & $\begin{array}{c}130 \\
(52.00)\end{array}$ & 0.02 \\
\hline & No & $\begin{array}{c}51 \\
(42.50)\end{array}$ & $\begin{array}{c}69 \\
(57.50)\end{array}$ & $\begin{array}{c}120 \\
(48.00)\end{array}$ & \\
\hline \multirow[t]{2}{*}{ Anoestrous } & Yes & $\begin{array}{c}60 \\
(40.27)\end{array}$ & $\begin{array}{c}89 \\
(59.73)\end{array}$ & $\begin{array}{c}149 \\
(59.60)\end{array}$ & 0.45 \\
\hline & No & $\begin{array}{c}45 \\
(44.55)\end{array}$ & $\begin{array}{c}56 \\
(55.45)\end{array}$ & $\begin{array}{c}101 \\
(40.40)\end{array}$ & \\
\hline \multirow[t]{2}{*}{ Milk fever } & Yes & $\begin{array}{c}18 \\
(40.00)\end{array}$ & $\begin{array}{c}27 \\
(60.00)\end{array}$ & $\begin{array}{c}45 \\
(18.00)\end{array}$ & 0.09 \\
\hline & No & $\begin{array}{c}87 \\
(42.44)\end{array}$ & $\begin{array}{c}118 \\
(57.56)\end{array}$ & $\begin{array}{c}205 \\
(82.00)\end{array}$ & \\
\hline \multirow[t]{2}{*}{ Ketosis } & Yes & $\begin{array}{c}9 \\
(34.62)\end{array}$ & $\begin{array}{c}17 \\
(65.38)\end{array}$ & $\begin{array}{c}26 \\
(10.40)\end{array}$ & 0.64 \\
\hline & No & $\begin{array}{c}96 \\
(42.86)\end{array}$ & $\begin{array}{c}128 \\
(57.14)\end{array}$ & $\begin{array}{c}224 \\
(89.60)\end{array}$ & \\
\hline \multirow[t]{2}{*}{ Metritis } & Yes & $\begin{array}{c}17 \\
(30.36)\end{array}$ & $\begin{array}{c}39 \\
(69.64)\end{array}$ & $\begin{array}{c}56 \\
(22.40)\end{array}$ & $4.01^{*}$ \\
\hline & No & $\begin{array}{c}88 \\
(45.36)\end{array}$ & $\begin{array}{c}106 \\
(54.64)\end{array}$ & $\begin{array}{c}194 \\
(77.60)\end{array}$ & \\
\hline \multirow[t]{2}{*}{$\begin{array}{l}\text { Repeat } \\
\text { breeding }\end{array}$} & Yes & $\begin{array}{c}24 \\
(32.00)\end{array}$ & $\begin{array}{c}51 \\
(68.00)\end{array}$ & $\begin{array}{c}75 \\
(30.00)\end{array}$ & $4.39^{*}$ \\
\hline & No & $\begin{array}{c}81 \\
(46.29)\end{array}$ & $\begin{array}{c}94 \\
(53.71)\end{array}$ & $\begin{array}{c}175 \\
(70.00)\end{array}$ & \\
\hline
\end{tabular}

Figures in parenthesis indicate percentage; ${ }^{*}=$ Significant at $(p=0.05)$

$(60 \%)$ prevalence was observed in anoestrus.

Parameters like dry period, normal calving, heats missed after calving were found to be non-significantly different between farmers who has taken training and not. Sharma et al. (2014) also revealed that pre training knowledge (3.64\%) on nutritional and management strategies increased to $6.39 \%$ with training. Kaur et al. (2018) also reported that there was significant relationship $(p<0.01)$ between social participation and mass media exposure for livestock farmer. It means that
Table 3: Impact of training on management, breeding and feeding practices

\begin{tabular}{|c|c|c|c|c|c|}
\hline $\begin{array}{l}\text { Param- } \\
\text { eter }\end{array}$ & Category & Impact & $\begin{array}{c}\text { No } \\
\text { impact }\end{array}$ & $\begin{array}{c}\text { Overall } \\
(n=250)\end{array}$ & $\begin{array}{c}\chi^{2} \\
\text { Value }\end{array}$ \\
\hline \multirow{3}{*}{$\begin{array}{l}\text { Dry pe- } \\
\text { riod (in } \\
\text { months) }\end{array}$} & $<1$ & $\begin{array}{c}4 \\
(57.14)\end{array}$ & $\begin{array}{c}3 \\
(42.86)\end{array}$ & $7(2.80)$ & 0.80 \\
\hline & $1-2$ & $\begin{array}{c}45 \\
(42.86)\end{array}$ & $\begin{array}{c}60 \\
(57.14)\end{array}$ & $\begin{array}{c}105 \\
(42.00)\end{array}$ & \\
\hline & $>2$ & $\begin{array}{c}56 \\
(40.58)\end{array}$ & $\begin{array}{c}82 \\
(59.42)\end{array}$ & $\begin{array}{c}138 \\
(55.20)\end{array}$ & \\
\hline
\end{tabular}

$\begin{array}{llllll}\text { Special Yes } & 68 & 50 & 118 & 22.40^{* *}\end{array}$ $\begin{array}{llll}\text { dry feed } \quad(57.63) & (42.37) & (47.20)\end{array}$

\begin{tabular}{|c|c|c|c|c|c|}
\hline & No & $\begin{array}{c}37 \\
(28.03)\end{array}$ & $\begin{array}{c}95 \\
(71.97)\end{array}$ & $\begin{array}{c}132 \\
(52.80)\end{array}$ & \\
\hline \multirow{2}{*}{$\begin{array}{l}\text { Special } \\
\text { mineral } \\
\text { mixture }\end{array}$} & Yes & $\begin{array}{c}10 \\
(18.18)\end{array}$ & $\begin{array}{c}45 \\
(81.82)\end{array}$ & $\begin{array}{c}55 \\
(22.00)\end{array}$ & $16.42^{* *}$ \\
\hline & No & $\begin{array}{c}95 \\
(48.72)\end{array}$ & $\begin{array}{c}100 \\
(51.28)\end{array}$ & $\begin{array}{c}195 \\
(78.00)\end{array}$ & \\
\hline \multirow[t]{2}{*}{$\begin{array}{l}\text { Normal } \\
\text { calving }\end{array}$} & Yes & $\begin{array}{c}109 \\
(55.61)\end{array}$ & $\begin{array}{c}87 \\
(44.39)\end{array}$ & $\begin{array}{c}196 \\
(78.40)\end{array}$ & 2.12 \\
\hline & No & $\begin{array}{c}36 \\
(66.67)\end{array}$ & $\begin{array}{c}18 \\
(33.33)\end{array}$ & $\begin{array}{c}54 \\
(21.60)\end{array}$ & \\
\hline \multirow{3}{*}{$\begin{array}{l}\text { Heat } \\
\text { missed } \\
\text { after } \\
\text { calving }\end{array}$} & $\begin{array}{l}\text { Not } \\
\text { missed }\end{array}$ & $\begin{array}{c}58 \\
(63.74)\end{array}$ & $\begin{array}{c}33 \\
(36.26)\end{array}$ & $\begin{array}{c}91 \\
(36.40)\end{array}$ & 2.71 \\
\hline & $\begin{array}{l}\text { More } \\
\text { than } 1\end{array}$ & $\begin{array}{c}11 \\
(64.71)\end{array}$ & $\begin{array}{c}6 \\
(35.29)\end{array}$ & $\begin{array}{c}17 \\
(6.80)\end{array}$ & \\
\hline & Only one & $\begin{array}{c}76 \\
(53.52)\end{array}$ & $\begin{array}{c}66 \\
(46.48)\end{array}$ & $\begin{array}{c}142 \\
(56.80)\end{array}$ & \\
\hline \multirow[t]{4}{*}{$\begin{array}{l}\text { Concep- } \\
\text { tion rate }\end{array}$} & $<50$ & $\begin{array}{c}6 \\
(20.69)\end{array}$ & $\begin{array}{c}23 \\
(79.31)\end{array}$ & $\begin{array}{c}29 \\
(11.60)\end{array}$ & $22.55^{*}$ \\
\hline & $50-60$ & $\begin{array}{c}16 \\
(24.24)\end{array}$ & $\begin{array}{c}50 \\
(75.76)\end{array}$ & $\begin{array}{c}66 \\
(26.40)\end{array}$ & \\
\hline & $\begin{array}{l}>60 \text { less } \\
\text { than } 80\end{array}$ & $\begin{array}{c}38 \\
(55.07)\end{array}$ & $\begin{array}{c}31 \\
(44.93)\end{array}$ & $\begin{array}{c}69 \\
(27.60)\end{array}$ & \\
\hline & $\geq 80$ & $\begin{array}{c}45 \\
(52.33)\end{array}$ & $\begin{array}{c}41 \\
(47.67)\end{array}$ & $\begin{array}{c}86 \\
(34.40)\end{array}$ & \\
\hline
\end{tabular}

Figures in parenthesis indicate percentage; ${ }^{*}=$ Significant at $(p=0.05) ; * *=$ Significant at $(p=0.01)$

with more training, the awareness of farmers regarding various aspects (management, breeding and feeding) of animal husbandry has also improved.

\section{Conclusion}

Knowledge level of dairy farmers about various recommended practices in relation to management, breeding and feeding practices was not very good. But the farmers who underwent training were more aware than who did not take training. 
Hence, proper inclusion of topic on transitional period management during training programmes is the need of an hour for improving not only reproduction potential, production potential but also the health status of an animal.

\section{References}

Agarwal, S.K., Singh, S.K., Rajkumar, R., 2005. Reproductive disorders and their management in cattle and buffalo: $\mathrm{A}$ review. Indian Journal of Animal Science 75(7), 858-873.

Aparna., Hundal, J.S., 2016. Impact of specialised trainings of dairy farming on the knowledge level of farmers in Punjab. Veterinary Science Research Journal 7(2), 79-82.

Aulakh, G.S., Yadav, J.S., Singh, R., 2011. Knowledge level of dairy farmers regarding recommended buffalo management practices. Journal of Dairying, Foods and Home Science 30(2), 147-149.

Chander, M., Dutt, T., Ravikumar, R., Subrahmanyeswari, B., 2010. Livestock technology transfer service in India: A review. The Indian Journal of Animal Science 80, 1115-1125.

Dua, K., 2003. Comparative disease susceptibility of cattle and buffalo in Punjab (India), in Proceedings $10^{\text {th }}$ International Symposium on Veterinary Epidemiology Economics, Vina del Mar, Chile, 92 (Available at: www. sciquest.org.nz/elibrary)

Grummer, R.R., 1995. Impact of changes in organic nutrient metabolism on feeding the transition dairy cow. Journal of Animal Sciences 73, 2820-2833.

Kasrija, R., 2016. Effectiveness of instructional material designed on the basis of felt needs of the dairy farmers of Punjab regarding common reproductive conditions. Ph.D. Dissertation, Guru Angad Dev Veterinary and Animal Sciences University, Ludhiana, India.

Kasrija, R., Verma, H.K., Sharma, R.K., 2016(a). Reproduction Acquaintance level (RAL) of dairy farmers in western region of Punjab. Indian Veterinary Journal 93(04), 11-13.

Kasrija, R., Verma, H.K., Gandotra, V.K., 2016(b). Assessment of Reproductive disorder remedial practice adoption (RDRPA) by dairy farmers in undulating plain region of Punjab. Indian Journal of Animal Reproduction 37(1), 43-44.

Kaur, N., Singh, P., Kasrija, R., Verma, H.K., 2018. Assessing Trainee's Profile for Better Execution of Livestock Training Course. International Journal of Current Microbiology and Applied Science 7(11), 561-566.

Melesse, K., Jemal, J., Melesse, A., 2013. Factors affecting the level of adoption of dairy technologies in Ada'a and Lume Districts, East Shoa Ethiopia. Agricultural Science Research Journals 3(8), 237-243.

Mir, A.Q., Bansal, B.K., Gupta, D.K., 2015. Short term changes in teats following machine with respect to quarter health status in cows. Journal of Animal Research 5(3), 467-471.

Parmar, S.S., 2014. Prevalence of common reproductive problems in dairy animals with respect to management practices in different agro-climatic zones of Punjab M.V.Sc. Thesis, Guru Angad Dev Veterinary and Animal Sciences University, Ludhiana, India.

Sharma, M., Singh, G., Keshava., 2014. Impact evaluation of training programmes on dairy farming in Punjab state. Indian Research Journal of Extension Education 14(1), 105-109.

Tewari, D., Jain, R.K., Dhakad, R.K., 2010. Nutritional status and blood biochemical parameters in anoestrus crossbred cattle in Malwa region of Madhya Pradesh. Indian Journal of Animal Nutrition 33, 138-143.

Thakur, N., 2018. Studies on feeding practices adopted during transitional period by dairy farmers of Punjab. M.V.Sc. thesis, Guru Angad Dev Veterinary and Animal Sciences University, Ludhiana, India.

Thakur, N., Singh, P., Deshmukh, B., Kasrija, R., 2018. Relationship of demographic profile of dairy farmers with transitional diseases in Punjab. International Journal of Current Microbiology and Applied Science 7(8), 3032-3037. 